\title{
Blended Chitosan and Polyvinyl Alcohol Membrane for Pervaporation Separation Methanol/Methyl tert-Butyl Ether Mixture. (II) Effect of Operating Parameters
}

\author{
M. G. Mohd Nawawia,b*, Zafifah Zamruda,b, Z. Idhamb , O. Hassanª, N. Mohd Sakria \\ ${ }^{a}$ Department of Chemical Engineering, Faculty of Chemical Engineering, Universiti Teknologi Malaysia, 81310 UTM Johor Bahru, Johor, Malaysia \\ ${ }^{b}$ Centre of Lipid Engineering and Applied Research, Universiti Teknologi Malaysia, 81310 UTM Johor Bahru, Johor, Malaysia
}

*Corresponding author: ghazali@cheme.utm.my

\section{Article history}

Received :11 November 2012

Received in revised form

7 October 2013

Accepted :15 October 2013

\section{Graphical abstract}

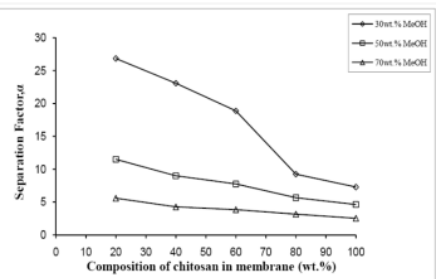

\begin{abstract}
Blend chitosan and polyvinyl alcohol (PVA) composite membranes were developed by mixing PVA and chitosan solutions at appropriate ratios. Pervaporation separation of the membrane was tested for methanol and MTBE mixture at different feed concentrations and temperature. The pervaporation performances were studied and evaluated and compared to the composite chitosan membrane. Flux increased with the increasing concentration of methanol in the feed. Separation factor was highest for the $20 \mathrm{wt} \%$ chitosan-containing blend membrane. The blend membrane containing $20-40 \mathrm{wt} \%$ of chitosan at feed temperature of $50^{\circ} \mathrm{C}$ exhibited permeation flux in between $52.28 \mathrm{~g} / \mathrm{m}^{2} . \mathrm{hr}$ to $66.92 \mathrm{~g} / \mathrm{m}^{2}$.hr with the separation factor of 53.22 to 81.00 .
\end{abstract}

Keywords: Chitosan; polyvinyl alcohol; membrane; pervaporation; methyl-tert butyl ether; methanol

\begin{abstract}
Abstrak
Komposit membran yang terdiri daripada campuran kitosan dan polivinil alkohol (PVA) dengan nisbah campuran yang berlainan telah dihasilkan. Membran yang dihasilkan diuji untuk proses pemisahan pervaporasi campuran metanol dan MTBE pada suhu dan kepekatan suapan yang pelbagai. Prestasi proses pemisahan tersebut telah dinilai dan dibandingkan dengan prestasi pemisahan menggunakan kitosan komposit membran. Jumlah aliran pada umumnya meningkat dengan peningkatan jumlah kepekatan suapan methanol di dalam campuran. Faktor pemisahan tertinggi dicatatkan pada campuran membran yang mengandungi $20 \%$ berat kitosan. Campuran membran dengan $20-40 \%$ berat kitosan mencatatkan aliran penyerapan antara $52.28 \mathrm{~g} / \mathrm{m}^{2} . \mathrm{j}$ dan $66.92 \mathrm{~g} / \mathrm{m}^{2} . \mathrm{j}$ dengan factor pemisahan antara 53.22 dan 81.00.
\end{abstract}

Kata kunci: Kitosan; polivinil alcohol; membran; pervaporasi; metil-tert butil eter; metanol

(C) 2013 Penerbit UTM Press. All rights reserved.

\subsection{INTRODUCTION}

Pervaporation, which name originates from a combination of the terms permeation and vaporization, is a hybrid between a liquid and a gas separation process [1]. It is based on the partial evaporation of feed components through a dense membrane. Permeate is further condensed in a separated vessel by means of low temperature or gas carrier stream [2]. Among the membrane processes, pervaporation technique is considered to be the best process in separating the organic mixtures especially for the close boiling point and azeotropic mixtures due to its high separation efficiencies coupled with energy saving [3]. Pervaporation is also being recognized as an effective process for separating mixtures consisting of heat-sensitive compounds and isomers [4]. These mixtures cannot be separated or can only be separated with great effort by conventional methods in example, distillation, fractional crystallization and extraction. In pervaporation fundamental work, Binning et al., [5] described pervaporation processes for the separation of a number of liquid mixtures. They emphasized the high efficiency and economical advantages of pervaporation processes compared to convectional techniques, especially for the separation and dehydration of azeotrope-forming aqueous-organic mixtures.

There are three applications of pervaporation; dehydration of organic solvents (water removal from organics), removal of organic compounds from aqueous solution (organic removal from water) and the separation of organic mixtures. The separation of organic mixtures using pervaporation process has been widely studied because of the importance of the separation process in the chemical and petrochemical industries. The separation of 
aromatic/aliphatic,

aromatic/cycloaliphatic

[6], stryrene/ethylbenzene [7], and alcohols liquid mixtures has been recently reported. Methyl tert-butyl ether (MTBE), ethyl-tert butyl ether (ETBE), tert-amyl methyl ether (TAME), etc. are being extensively used as lead-free octane enhancers [8]. The first plant for organic/organic separation by pervaporation was reported by Air Products, a company in the USA for the removal of methanol from methyl tert-butyl ether (MTBE) in the production of octane enhancer for fuel blends [9].

Blended chitosan and PVA membrane has been developed and characterized as reported in the previous paper. In this study, the major focus is to further investigate the swelling of the membrane in methanol/MTBE mixture and considers the effect of membrane composition, feed concentration and feed temperature. The membranes were characterized and evaluated based on the pervaporation performance for the methanol/MTBE mixture in terms of the overall flux, individual flux, separation factor and pervaporation separation index (PSI).

\subsection{EXPERIMENTAL}

\subsection{Pervaporation Apparatus}

Pervaporation cell used consisted of two detachable 316 stainless steel parts. The upper part was equipped with inlet and outlet of the feed mixtures. A porous stainless steel plates with pore size approximately $50 \mu \mathrm{m}$ and $1 \mathrm{~mm}$ thickness were fixed in the lower part of the cell supported the membrane. The lower and upper parts of the cell set in proper alignment and sealed tightly with 2 ethylene propylene diene monomer (EPDM) O-rings. The effective area for membrane permeation was $63.62 \mathrm{~cm}^{2}$. The feed tank was made from hardened stainless steel and had a maximum solution capacity of approximately 5 liters.

Figure 1 shows the schematic representation of the pervaporation apparatus. The feed mixture enters the cell through the inlet opening and leaves the cell through the outlet opening on the opposite site. The feed mixture was then circulated through the cell by a circulation pump which was controlled using control valve. The operation of this unit was in batch mode since the feed was continuously recycled back to the feed tank and the vapor permeate through the membrane was removed from the lower part of the cell, which was kept under vacuum pressure and condensed in a cold trap that was immersed in the liquid nitrogen. A control valve was used to control the downstream pressure. Pervaporation system was run for at least 1 hour for start up process until the permeation flow reached steady state. Permeate sample can only be collected after permeation reached steady state. Permeate sample was removed from the system and left to warm up to ambient temperature before being weighed and analyzed for the composition. The composition of permeate was analyzed using gas chromatography (GC).

\subsection{Pervaporation Experiments}

The performance of membranes has been investigated in terms of their permeation flux and separation factor. The total permeation flux, $J$ through the membrane is defined as:

Flux $_{0} J=\frac{Q}{A t}$

Where $Q$ is the weight $(\mathrm{g})$ of the permeate, $\mathrm{t}$ is the permeation time (h), and $A$ is the membrane area $\left(\mathrm{m}^{2}\right)$.

The separation is defined as:
Separation Factor $=\frac{\left(\mathrm{Y}_{\text {MEOH }} / \mathrm{Y}_{\text {MTEE }}\right)}{\left(\mathrm{X}_{\text {MEOH }} / \mathrm{M}_{\text {MTEE }}\right)}$

Where $\mathrm{Y}$ is the permeate composition and $\mathrm{X}$ is the feed composition.

In pervaporation process of polar/nonpolar solvent mixture of methanol/MTBE with the membranes made from the polarity polymer, methanol is a preferentially permeable component compared to MTBE, because methanol has comparatively strong polarity in the solution [4], and is able to display strong hydrogen interaction with the $\mathrm{OH}$ groups of PVA and chitosan. The solubility of methanol in chitosan/PVA membrane is far greater than that of MTBE, and also because the molecular size of methanol is much smaller than that of MTBE, methanol is liable to diffuse through the gaps between the chain sections of the polymer.

Since solubility and diffusivity of the feed mixture component in polymeric membranes are generally dependent on the operating temperature, pervaporation characteristic in the terms of flux is also dependent on the temperature. When the temperature of the feed is increased, the permeation rate generally follows an Arrhenius type law [10, 11]:

$I=A_{p} \exp \left(E_{p} / R T\right)$

Where $J$ is the total permeation flux $\left(\mathrm{kg} / \mathrm{m}^{2} . \mathrm{hr}\right) ; A_{p}$, the preexponential factor $\left(\mathrm{kg} / \mathrm{m}^{2} . \mathrm{hr}\right) ; E_{p}$, the activation energy of permeation $(\mathrm{kJ} / \mathrm{mol})$; $\mathrm{R}$, the gas constant $(\mathrm{kJ} / \mathrm{mol} . \mathrm{K})$; and $\mathrm{T}$ the operation temperature $(\mathrm{K})$. The value of the apparent activation energy of permeation varies in the range $17-63 \mathrm{~kJ} / \mathrm{mol}$. The apparent activation energy indicates the amount of energy required to facilitate diffusion of the permeating components through the membrane. Thus, the activation energy for diffusion of methanol should be lower than that for MTBE if the membrane is relatively more selective to methanol.

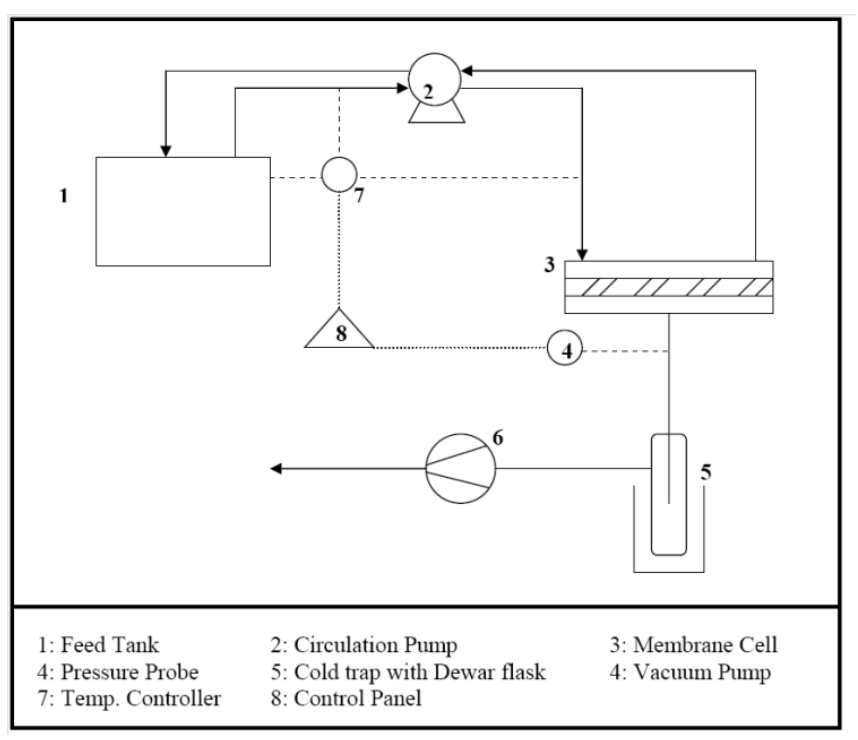

Figure 1 Schematic diagram of pervaporation apparatus

\subsection{RESULTS AND DISCUSSION}

The pervaporation experiments have been conducted in different feed concentrations in the attempt to determine the optimum condition of the respective membrane. Figure 2 shows the 
comparison of flux between four different ratios of blended chitosan and PVA composite membranes and unmodified chitosan composite membrane at room temperature versus concentration of methanol in the feed. The unmodified chitosan membrane refers to untreated pure chitosan membrane; no modifications were done on the pure chitosan membrane. Unmodified membrane exhibited the highest permeation flux at $259 \mathrm{~g} / \mathrm{m}^{2} . \mathrm{h}$ in $70 \mathrm{wt} \%$ feed concentration. The rise of methanol feed concentration resulted in the increasing of flux. This is very typical in the separation of methanol/MTBE by pervaporation. It is because the factor of the polarity in methanol compositions. It is known that chitosan and PVA are the hydrophilic membranes because of their hydroxyl groups [12].

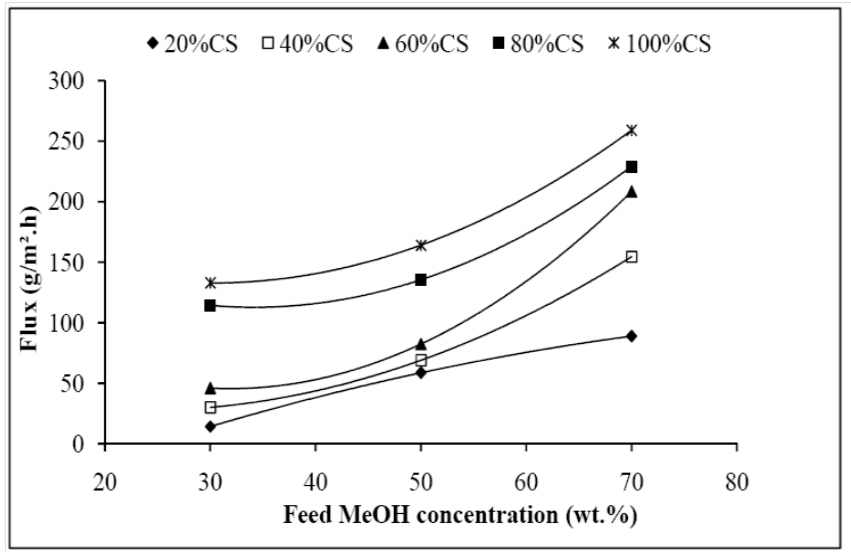

Figure 2 The permeation flux of different membranes in the different feed concentrations

Swelling of the membrane is generally defined as the weight fraction of permeating component inside the membrane relative to the weight of the dry membrane. Swelling is a result of interaction between the permeating component and the polymer and is very important factor in transport through nonporous membranes as in pervaporation. The mobility of the polymer chains increases with increasing swelling. The increase in the methanol concentration in the liquid feed increases the degree of swelling of the hydrophilic membrane, thus increasing the flux of the permeating components as indicated by Figure 2. Since the molecular size of MTBE is greater than that of methanol, the permeation flux of the former is more affected that that of the latter. Owing to this high hydrophilicity of the chitosan and PVA material, the membranes swelled more significantly in the solution with high methanol content [13]. With increasing methanol concentration in the feed mixture, because of a strong interaction between methanol and membranes, the membranes become more swollen and as a result, polymer chains become more flexible. The swelling effect increases the space available for diffusion, thus transport becomes easier. As a result, the flux increases with increasing methanol concentration in the feed.

However, at high concentrations of methanol in the feed, the permeation flux decreased as the PVA ratios in the membrane increased. This could be happening due to the structure of PVA and chitosan. PVA is aliphatic hydrophilic polymer but chitosan is cycloaliphatic hydrophilic polymer [14]. Therefore, PVA structure is more compact than that of chitosan. It can be seen that membrane containing $20 \mathrm{wt} \%$ chitosan has the lowest permeation flux even at $70 \mathrm{wt} \%$ feed concentration compared to the other membranes. This is because of the decrease in the total polymer concentration of the PVA content in the membrane.
Figure 3 shows the total and individual component (methanol and MTBE) permeation flux at $30 \mathrm{wt} \%$ methanol concentration. The permeation fluxes of the permeating components increase with the increase in the composition of chitosan in the membrane. As shown, the permeation flux of methanol is higher than that of MTBE for the whole range of the composition of chitosan in the membrane. It should be noted that for the whole range of composition of chitosan in the membrane the methanol flux is almost identical to the total flux which indicates that the membrane is more selective to methanol as compared to MTBE. The membrane containing $20 \mathrm{wt} \%$ chitosan has the lowest total permeation flux. This is due to the high composition of more condensed polymer network of PVA. The insertion of small amount of chitosan could have made certain parts of PVA compact network distorted and lead to higher free volume in the network. Therefore, further increase of chitosan in the membrane will allow higher permeation rate [15].

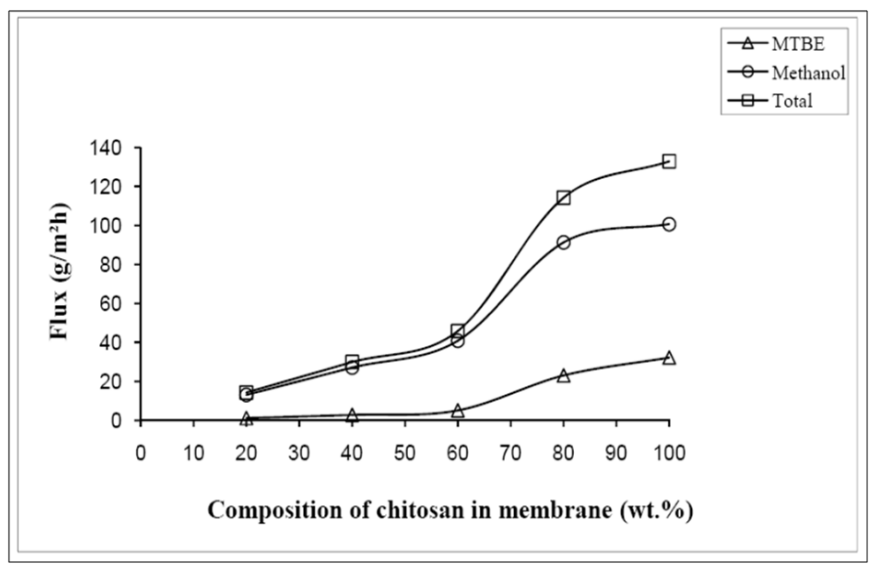

Figure 3 The permeation flux versus the concentration of chitosan for each component at $30 \mathrm{wt} \%$ methanol concentration

The separation factor of methanol and MTBE is shown in Figure 4. The separation factor decreased as both the chitosan composition in the membrane and methanol feed concentration increased. The highest separation factor achieved was between 20-40 wt $\%$ chitosan compositions in the membrane at $30 \mathrm{wt} \%$ methanol concentration. As shown by the figure, at $20 \mathrm{wt} \%$ of chitosan in the membrane, the highest separation factor $(\square \sim 24)$ was achieved using $30 \mathrm{wt} \%$ of methanol as the liquid feed. The separation factor reduced to about 23 when the chitosan content in the membrane increased to $40 \mathrm{wt} \%$ using the same liquid feed. Similar trends can be observed for the whole range of composition of chitosan in the membrane; the separation factor decreases with the chitosan content in the membrane. This may be attributed to a decrease in density of the membrane as higher dosage of chitosan added to the membrane. As the membrane become relatively less dense and the polymer network loosen, the membrane becomes less selective.

Since both chitosan and PVA can preferentially interact with $\mathrm{MeOH}$, they have the polarity factor. As the chitosan content in membrane increases, the selective diffusivity decreases because of the loosening of the polymer network. When the content of chitosan is high, the selectivity is low [13].

In the attempt to investigate the effect of temperature, the pervaporation separation was conducted at feed concentration of $30 \mathrm{wt} \%$ methanol. The variables are the composition of chitosan in the membrane and the feed temperature. Figure 5 shows the effect of feed temperature on the total permeation flux at different chitosan composition in the membrane. The figure shows the total 
permeation increased as the feed temperature increased for all five membranes at $30 \mathrm{wt} \%$ of methanol concentration in the feed. It could be due to the fact that the increase of feed temperature elevates the polymer thermal mobility and consequently leads to the rise of mass transport across the membrane. This is an agreement with physical reasoning that a larger driving force for flux leads to a higher flux [16].



Figure 4 Separation factor versus composition of chitosan in the membrane.

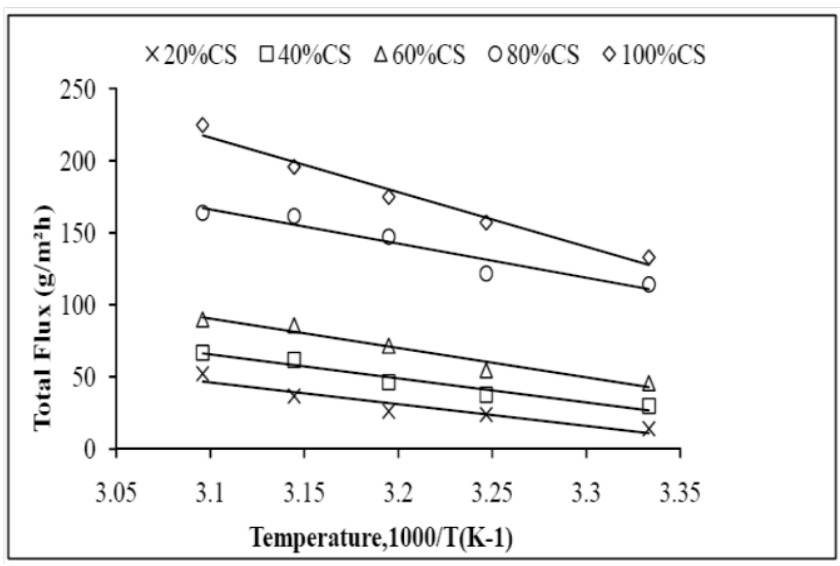

Figure 5 Effects of feed temperature on total permeation flux

Increasing temperature brings about higher molecular diffusivity [1]. Higher diffusivity allows molecules to penetrate through membrane faster and results in an increase of total flux. In addition, the increased of feed temperature could result in earlier phase transition of liquid inside the membrane because the required enthalpy for the transition is achieved faster when there is more heat supplied. The diffusivity of vapor is higher than liquid; therefore, the mass transport is faster and the total flux increases [14].

Figure 6 and 7 illustrate the effects of temperature on the individual flux and separation for the pervaporation of methanol and MTBE using blended chitosan and polyvinyl alcohol membranes. Figure $6 \mathrm{a}$ and $6 \mathrm{~b}$ show the Arrhenius relationships between methanol and MTBE with the feed temperature respectively. By comparing Figure $6 a$ and $6 b$, it could be concluded that for all the temperature range, the methanol flux is higher than that of MTBE. It should be noted also that both the methanol and MTBE flux increased with increasing feed temperature. In general,as the temperature increases, the thermal motion of polymer chain is intensified, creating more free volume in the polymer matrix, i.e., polymers possess larger free volumes at higher temperature [13]. Nam and Lee [13] reported the effects of operating temperatures on pervaporation of ethylene glycolwater mixtures. They found that, as temperature increases, the permeation flux increases and water concentration declined. Similar trend is observed for the dependency of separation factor on the feed temperature. In general, the separation factor increases with the increase in the feed temperature. However, unlike in the investigation of permeation flux, composite chitosan membrane has the lowest separation factor compared to other membranes. This is the normal trade off between the permeation flux and separation factor where high permeation flux gives low separation factor and vice versa.

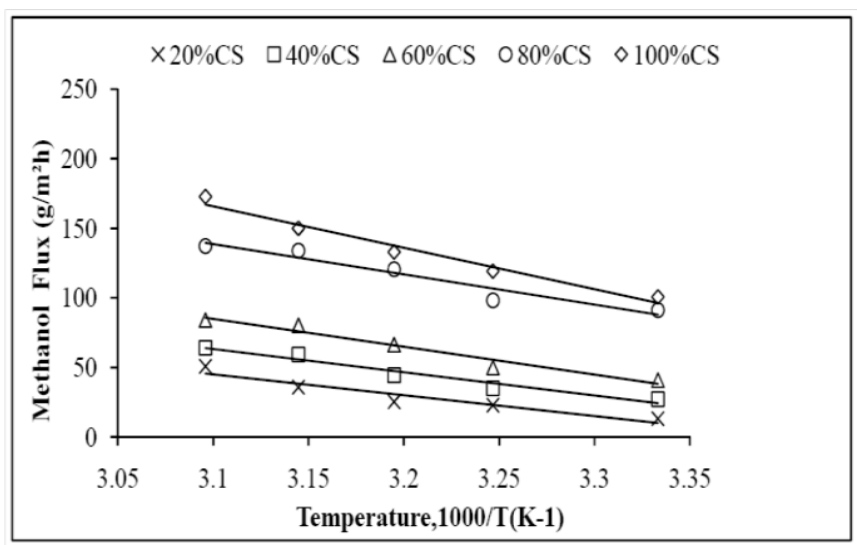

(a)

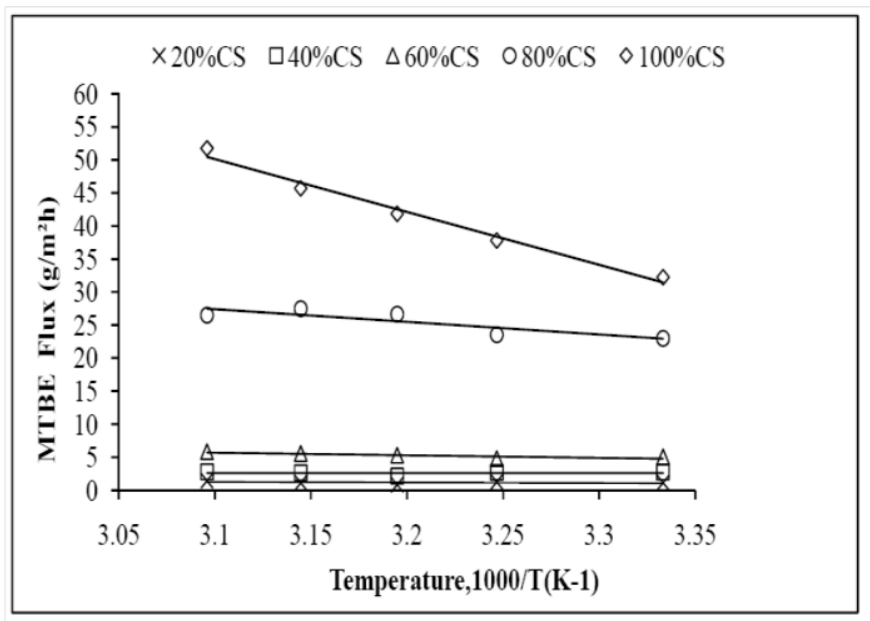

(b)

Figure 6 Effects of feed temperature on individual flux. (a) Methanol flux. (b) MTBE flux

\subsection{CONCLUSIONS}

The pervaporation experiments show that the membrane containing lower ratio of chitosan to PVA has better permeation flux and separation factor. The optimum preparation condition of modified chitosan composite membrane is as obtained for the membrane containing 20-40 wt $\%$ chitosan. The membrane will perform at the optimum pervaporation condition of $30 \mathrm{wt} \%$ of methanol concentration in the feed. At this condition, the flux obtained was between $52.28 \mathrm{~g} / \mathrm{m}^{2} . \mathrm{hr}$ and $66.92 \mathrm{~g} / \mathrm{m}^{2} . \mathrm{hr}$ with the separation factor between 53.22 and 81.00 . 




Figure 7 Separation factor at different feed temperature

\section{References}

[1] Nawawi, M. G. M. 1997. Pervaporation Dehydration of IsopropanolWater Systems Using Chitosan Membranes. Ph.D Thesis. University of Waterloo, Canada.

[2] Neel, J. 1995. Pervaporation. In Noble, R.D., and Stern, S.A. (Eds.). Membrane Separations Technology. Principle and Applications. Amsterdam: Elsevier Science. 143-209.

[3] Durmaz-Hilmioglu, N., Yildirim, A.E., Sakaoglu, A.S., and Tulbentci, S. 2001. Acetic Acid Dehydration by Pervaporation. Chem. Eng. Process. 40: $263-267$.

[4] Kim, S. G., Lim, G. T., Jegal, J., and Lee, K.H. 2000. Pervaporation Separation of MTBE (Methyl Tert-Butyl Ether) and Methanol Mixtures through Polyion Complex Composite Membranes Consisting of Sodium Alginate/Chitosan. J. Memb. Sci. 174: 1-15.
[5] Binning, R. C., Lee, R. J., Jennings, J. F., and Martin, E. C. 1961. Separation of Liquid Mixtures by Permeation. Industrial Engineering Chemical. 53: 45-50.

[6] Inui, K., Naguchi, T., Miyata, T., and Uragami, T. 1999. PV Characteristics of Methyl Methacrylate-Methacylic Acid Copolymer Membranes Ionically Crosslinked with Metal Ions Benzene/Cyclohexane Mixture. J. Appl. Polym. Sci. 71(2): 233-241.

[7] Cao, B., and Kajiuchi, T. 1999. Pervaporation Separation of StyreneEthyl Benzene Mixture using Poly(hexamethylene sebacate)-Based Polyurethane Membranes. J. Appl. Polym. Sci. 74(4): 753-761.

[8] Ray, S., and Ray, S.K. 2006. Synthesis of Highly Methanol Selective Membranes for Separation of Methyl Tertiary Butyl Ether (MTBE)Methanol Mixtures by Pervaporation. J. Memb. Sci. 278: 279-289.

[9] Chen, M. S. K., Markiewicz, G. R., and Venugopal, K. G. 1989. Development of Membrane Pervaporation TRIMTM Process for Methanol from CH3OH/MTBE/C4 Mixtures. AIChE Symp. Ser. 85: 82.

[10] Huang, R. Y. M., and Lin, V. J. C. 1968. Separation of Liquid Mixtures by using Polymer Membranes. I. Permeation of Binary Organic Liquid Mixtures through Polyethylene. J. App. Polym Sci. 12: 2165.

[11] Huang, R.Y.M., and Rhim, J.W.1991. Separation Characteristics of PV Membranes Separation Process. In: Huang, R.Y.M. (Ed.). Separation Pervaporation Membrane Separation Processes. Amsterdam: Elsevier. 111-180.

[12] Tan, S. H., Ahmad, A. L., Nawawi, M. G. M., and Hassan, H. 2002. Performance of Chitosan Membranes Crosslinked with Glutaraldehyde in Pervaporation Separation. J. ASEAN Committee Sci. Technol. 19: 69-83.

[13] Nam, S. Y., and Lee, Y. M. 1999. Pervaporation Separation of Methanol/Methyl t-Butyl Ether through Chitosan Composite Membrane Modified with Surfactants. J. Memb. Sci. 157: 63-71.

[14] Svang-Ariyaskul, A., Huang, R. Y. M., Douglas, P. L., Pal, R., Feng, X., Chen, P., and Liu, L. 2006. Blended Chitosan and Poly(vinyl alcohol) Membranes for the Pervaporation Dehydration of Isopropanol. J. Memb. Sci. 280: 815-823.

[15] Huang, R. Y. M., Pal, R., and Moon, G. Y. 1999. Crosslinked Chitosan Composite Membrane for the Pervaporation Dehydration of Alcohol Mixtures and Enhancement of Structural Stability of Chitosan/Polysulfone Composite Membranes. J. Memb. Sci. 160: 17-30.

[16] Won, W., Xianshe, F., and Darren, L. 2002. Pervaporation with Chitosan Membranes: Separation of Dimethyl Carbonate/Methanol/Water Mixtures. J. Memb. Sci. 209: 493-508. 